\title{
PRODUKTIVITAS RATUN SORGUM VARIETAS KAWALI DENGAN PEMUPUKAN BOKASHI FESES SAPI
}

\author{
Agnitje Rumambi, Malky Telleng, Wilhelmina Kaunang, Sjeny Malalantang \\ Fakultas Peternakan Universitas Sam Ratulangi Manado \\ e-mail: agnitjerumambi@ymail.com
}

\begin{abstract}
ABSTRAK
Penelitian ini bertujuan untuk mengetahui produktivitas ratun sorgum kawali yang diberikan pupuk bokashi feses sapi. Peneilitian ini menggunakan Rancangan Acak Lengkap (RAL) dengan 4 perlakuan dan 5 ulangan. Perlakuan terdiri dari Po =tanpa pemupukan, $\mathrm{P}_{1}=$ Pemupukan $4 \mathrm{~kg}, \mathrm{P} 2=$ Pemupukan $8 \mathrm{~kg}$, $\mathrm{P}_{3}=$ Pemupukan $12 \mathrm{~kg}$. Variabel yang diukur adalah jumlah anakan, tinggi tanaman, dan berat malai. Hasil analisis statistik menunjukan bahwa pemberian bokashi feses sapi memberikan pengaruh yang sangat nyata $(\mathrm{P}<\mathrm{O}, 01)$ terhadap jumlah anakan, tinggi tanaman, dan berat malai. Pemberian pupuk bokashi feces sapi dengan level $12 \mathrm{~kg}$ menghasilkan jumlah anakan, tinggi tanaman dan berat malai yang sangat nyata $(\mathrm{P}<\mathrm{O}, 01)$ lebih tinggi dari pada tanpa pemupukan, pemupukan $4 \mathrm{~kg}$ dan pemupukan $8 \mathrm{~kg}$. Disimpulkan bahwa pemberian pupuk bokashi feses sapi sampai dengan $12 \mathrm{~kg} /$ petak menghasilkan jumlah tunas, tinggi tanaman, dan berat malai tanaman ratun sorgum yang lebih tinggi. Panen ratun menghasilkan tinggi tanaman $16,65 \%$ dan berat malai 2,65\% lebih tinggi dari pada panen pertama.
\end{abstract}

Kata kunci: Bokashi, kawali, produktivitas, ratun, sorgum

\begin{abstract}
This study aims to determine the effect of bokashi cow feces on the productivity of ratoon sorghum variety of kawali. This research design used was completely randomized design (CRD), which consists of 4 treatments and 5 replications. The treatment consists of $\mathrm{Po}=$ without fertilization, $\mathrm{P} 1=4 \mathrm{~kg}$ of fertilization, $\mathrm{P}_{2}=8 \mathrm{~kg}$ of fertilization, $\mathrm{P}_{3}=12 \mathrm{~kg}$ of fertilization. The measured variables are number of tillers, plant height, and panicle weight. Result of the analysis showed that treatment with $12 \mathrm{~kg} / \mathrm{plot}$ provides highly significant effect ( $\mathrm{P}<0.01)$ of the number of tillers, plant height, and panicle weight compared without fertilization, 4 and $8 \mathrm{~kg} /$ plot fertilization. Based on this research it can be concluded that cattle feces bokashi as the organic fertilizer up to $12 \mathrm{~kg}$ produced the best effect on number of tillers, plant height, and panicle weight. Ratoon harvest yields plant height $16,65 \%$ and panicle weight 2,65\% higher than first harvest.
\end{abstract}

Keywords: Bokashi, kawali productivity, ratoon, sorghum

\section{PENDAHULUAN}

Hijauan merupakan sumber pakan utama bagi ternak ruminansia, karena ketersediaan hijauan makanan ternak yang berkualitas sangat dibutuhkan untuk menunjang produktivitas ternak. Sorgum (Sorghum bicolor (L.) Moench) merupakan tanaman serealia yang potensial untuk dibudidayakan dan dikembangkan sebagai hijauan pakan ternak ruminansia, khususnya pada daerah-daerah marginal dan kering di Indonesia. Sorgum mempunyai daya adaptasi agroekologi yang luas, tahan terhadap kekeringan, produksi tinggi, membutuhkan input lebih sedikit serta lebih tahan terhadap hama dan penyakit dibanding tanaman pangan lain. Potensi daun sorgum manis sekitar 14-16\% dari bobot segar batang atau sekitar 3 ton daun segar/ha dari total produksi 20 ton/ha. Sorgum memiliki kandungan nutrisi yang tinggi, biji sorgum yaitu: protein 10,26\%; Serat kasar 2,72\%; Lemak 2,70\%; Ca 0,90\%; dan P $0,38 \%$ dan kandungan protein daun sorgum lebih tinggi dari rumput gajah dan pucuk tebu (Rumambi, 2013) sehingga dapat dibudidayakan secara intensif sebagai sumber pakan hijauan bagi ternak ruminansia.

Salah satu teknik bubidaya yang perlu dipelajari dalam pengembangan sorgum adalah sistem ratun. Batang tanaman musim tanam pertama dipotong, dibiarkan tumbuh kembali dan dibudidayakan seperti sorgum yang ditanam dari benih. Beberapa keuntungan penerapan ratun pada tanaman sorgum yaitu penghematan benih karena pada musim tanam kedua tidak diperlukan benih lagi. Penghematan waktu karena tidak diperlukan lagi waktu untuk pengolahan tanah dan penanaman. Selain itu tanaman 
hasil ratun dapat dipanen lebih cepat, kebutuhan air lebih sedikit, serta biaya produksi lebih rendah karena penghematan dalam pengolahan tanah dan penggunaan benih. Pemotongan batang dimaksudkan untuk merangsang tumbuhnya tunas dan akar baru sehingga meningkatkan jumlah anakan dan jumlah daun tanaman (Mekbib, 2009; Puspitasari et al., 2012).

Kesuburan tanah sangat penting dalam upaya peningkatan produktivitas tanaman sorgum dengan penambahan unsur hara melalui fermentasi dengan pemberian EM4 (Effective Microorganisme-4). Pemupukan dapat menyediakan unsur hara yang diperlukan oleh tanaman dengan pemberian dosis yang tepat di harapkan dapat meningkatkan produktivitas tanaman sorgum. Bokashi merupakan salah satu jenis pupuk yang dapat menggantikan kehadiran pupuk kimia (anorganik) dalam menambah kesuburan tanah sekaligus memperbaiki kerusakan fisik, kimia, dan biologi tanah akibat pemakaian pupuk secara berlebihan. Bokashi merupakan hasil fermentasi bahan organik dari limbah pertanian (pupuk kandang, jerami, dan sekam serbuk gergaji dengan menggunakan EM4 (Gao et al., 2012; Atikah, 2013). EM4 merupakan bakteri pengurai bahan organik yang memiliki keunggulan antara lain memperbaiki kondisi tanah, menekan pertumbuhan mikroba yang menimbulkan penyakit dan memperbaiki efisiensi penggunaan bahan organik oleh tanaman. Kelebihan bahan organik bermanfaat dalam bidang peternakan, perikanan, dan pengelolahan limbah (Ruhukai, 2011). Selain itu, EM4 tidak meninggalkan efek residu yang negatif seperti bau dan panas. Berdasarkan latar belakang tersebut maka telah dilakukan penelitian tentang pemanfaatan bokashi feses sapi terhadap produktivitas ratun sorgum varietas kawali.

\section{MATERI DAN METODE}

Benih sorgum variates kawali, feses sapi, EM4, gula putih, air sumur, serbuk gergaji, dedak halus dan tanah sebagai media tanam. Alat yang digunakan adalah: Cangkul, meter, timbangan, parang, kamera, bambu, paku, kertas HVS warna, tali, plastik, gunting, gelas ukur, kamera, sekop, ember, terpal, termometer dan alat tulis menulis.

\section{Pembuatan Bokashi Feses Sapi}

Persiapan bahan berupa larutan $\mathrm{EM}_{4}+$ gula + air dicampur merata. Selanjutnya penyiapan bahanbahan pengisi seperti feses sapi, dedak halus, sekam padi, serbuk gergaji, semua bahan pengisi di campur secara bertahap. Bahan olahan ditutup menggunakan karung goni. Pengecekan suhu dilakukan setiap 5-6 jam, apabila terjadi peningkatan suhu pada bahan olahan perlu dilakukan pembongkaran dengan cara membolakbalikan bahan tersebut agar terjadi penurunan suhu kemudian ditutup kembali. Bokashi dapat digunakan apabila telah memiliki ciri berwarna coklat kehitaman, tekstur lembut, gembur, tidak panas, dan tidak berbau busuk.

Penelitian ini merupakan penelitian lanjutan, jadi pemupukan dilakukan pada penanaman sorgum yang pertama, untuk mengetahui apakah pemupukan yang dilakukan dengan bokashi feses sapi masih memberikan pengaruh terhadap produktivitas anakan sorgum.

\section{Rancangan}

Rancangan yang digunakan adalah Rancangan Acak Lengkap (RAL) (Steel dan Torrie, 1995) terdiri atas 4 perlakuan dan 5 ulangan sehingga diperoleh 20 satuan percobaan.

Petak yang digunakan berukuran 2 × 3 meter, jumlah tanaman perpetak adalah 18 tanaman dengan jarak tanam 50 x $75 \mathrm{~cm}$. Perlakuan yang diberikan adalah :

$$
\begin{aligned}
& \text { Po }=\text { Tanpa Pemupukan } \\
& \text { P1 }=\text { Pupuk Bokashi } 4 \mathrm{~kg} \\
& \text { P2 }=\text { Pupuk Bokashi } 8 \mathrm{~kg} \\
& \text { P3 }=\text { Pupuk Bokashi } 12 \mathrm{~kg}
\end{aligned}
$$

Pembersihan tanah dengan cara pembajakkan atau pembongkaran tanah kemudian dilakukan penyisiran agar bersih dari sisa-sisa tanaman dan rumput liar dilanjutkan dengan pembuatan petak sebanyak 20 petak dengan ukuran $2 \times 3$ meter, jarak antar petak adalah $50 \times 75 \mathrm{~cm}$. Tanah yang telah dibuat petak-petak tadi dibiarkan selama 1 minggu untuk membiarkan kesempatan bagi rumput liar tumbuh kemudian dicangkul kembali. Dilanjutkan dengan pemberian pupuk sesuai perlakuan pada tiap-tiap petak.

Penanaman dilakukan dengan cara tunggal, dimana setiap lubang ditanami 23 butir, setelah tanaman berumur 1 minggu dilakukan penjarangan dengan meninggalkan satu tanaman per lubang. Setiap petak ditanami 18 tanaman sehingga keseluruhan petak berjumlah 360 tanaman. Pemeliharaan tanaman meliputi penyiangan dilakukan apabila muncul tanaman pengganggu dalam petak percobaan. Penyemprotan dilakukan menggunakan furadan dan sefin pada tanaman yang terserang hama.

Pengambilan data dilakukan 2 minggu setelah pemotongan batang tanaman utama terhadap jumlah anakan, tinggi tanaman, dan berat malai pada umur 90 hari. Peubah yang diukur adalah jumlah anakan, tinggi tanaman $(\mathrm{cm})$ dan berat malai $(\mathrm{g} / \mathrm{tanaman})$ 


\section{HASIL DAN PEMBAHASAN}

\section{Tinggi Tanaman}

Pengaruh perlakuan terhadap tinggi tanaman panen pertama dapat dilihat pada Tabel 1 dan pengaruh perlakuan terhadap tinggi tanaman ratun dapat dilihat pada Tabel 2.. Terlihat bahwa perlakuan pemupukan memberikan pengaruh yang sangat nyata $(\mathrm{P}<0,01)$ terhadap tinggi tanaman. Semakin tinggi level pupuk bokashi akan menghasilkan tanaman yang lebih tinggi. Pemberian bokashi $12 \mathrm{~kg}$ menghasilkan tanaman yang lebih tinggi $(168,2 \mathrm{~cm})$ dibandingkan dengan pemberian bokashi $4 \mathrm{~kg}(151,8 \mathrm{~cm})$ dan tanpa pemupukan $(139,2 \mathrm{~cm})$.

Pemberian pupuk bokashi $12 \mathrm{~kg}$ menghasilkan tinggi tanaman tertinggi yaitu 196,2 cm diikuti dengan pemberian bokashi $8 \mathrm{~kg}(176 \mathrm{~cm})$, pemberian bokashi $4 \mathrm{~kg}(162,6 \mathrm{~cm})$ dan yang terendah tanpa pemberian bokashi (147 cm). Pemberian bokashi 12 kg menghasilkan tinggi tanaman yang tertinggi baik pada panen pertama maupun ratun. Panen ratun menghasilkan tinggi tanaman yang lebih tinggi 16,65\% dari pada panen pertama.

Semakin tinggi tanaman dengan meningkatnya level pemberian bokashi disebabkan karena adanya sumbangan bahan organik tanah berasal dari bokashi yang merupakan pupuk organik yang baik. Sarief (1986) mengatakan bahwa tersedianya unsur hara yang cukup saat saat pertumbuhan maka proses fotosintesis akan lebih aktif, sehingga pemanjangan, pembelahan dan diferensiasi sel akan lebih baik. Jadi semakin banyak unsur hara yang dapat diserap oleh tanaman sorgum maka proses proses fotosintesis akan lebih aktif sehingga akan mempercepat pertumbuhan tinggi tanaman. Hasil penelitian ini lebih tinggi dari penelitian Imban et al. (2017) yang menghasilkan tinggi tanaman 168,20 cm menggunakan bokashi feses sapi. Lain halnya dengan penelitian Rumambi (2012) menggunakan pupuk hayati fungi mikoriza arbuscula (FMA) dan aplikasi fosfat alam menghasilkan tinggi tanaman yang lebih tinggi yaitu $247,86 \mathrm{~cm}$.

\section{Berat Malai}

Pengaruh perlakuan terhadap berat malai panen pertama dapat dilihat pada Tabel 1. Terlihat bahwa perlakuan pemupukan memberikan pengaruh yang sangat nyata $(\mathrm{P}<\mathrm{O}, \mathrm{O} 1)$ terhadap berat malai. Semakin tinggi level pupuk bokashi akan menghasilkan malai yang lebih berat. Pemberian bokashi $12 \mathrm{~kg}$ menghasilkan berat malai yang lebih tinggi $(377,8 \mathrm{~g})$ dibandingkan dengan pemberian bokashi $4 \mathrm{~kg}(282,6$ g) dan tanpa pemupukan $(282,6 \mathrm{~g})$.

Pengaruh perlakuan terhadap berat malai ratun dapat dilihat pada Tabel 2. Nilai rataan perlakuan $\mathrm{P}_{3}$ memberikan Berat Malai tertinggi yaitu 387,8 g diikuti dengan P2 (345,6 g), P1 (309,4 g) dan yang terendah Po (286 g). Hasil analisis sidik ragam menunjukkan bahwa perlakuan memberikan pengaruh yang berbeda sangat nyata $(\mathrm{P}<0,01)$ terhadapberat malai. Uji lanjut BNJ menunjukkan bahwa perlakuan $\mathrm{P}_{3}$ berbeda sangat nyata $(\mathrm{P}<\mathrm{O}, \mathrm{O} 1)$ lebih tinggi dibandingkan $\mathrm{Po}$ dan $\mathrm{P} 1$ ) sedangkan $\mathrm{P}_{3}$ dan $\mathrm{P} 2$ memberikan pengaruh yang berbeda tidak nyata $(\mathrm{P}>0,05)$ terhadap berat malai. Pemberian bokashi $12 \mathrm{~kg}$ menghasilkan berat malai tanaman yang tertinggi baik pada panen pertama maupun ratun. Panen ratun menghasilkan berat malai tanaman yang lebih tinggi 2,65\% dari pada panen pertama.

Semakin tinggi level pupuk kandang maka makin tinggi berat malai, dikarenakan adanya pemberian pupuk bokashi feses sapi yang dapat memperbaiki sifat fisik, kimia dan biologi tanah sehingga tanah menjadi lebih subur. Hal ini karena unsur hara cukup yang berasal dari dalam tanah dan dari pupuk bokashi yang diberikan berpengaruh pada pembentukan biji untuk bobot malai. Menurut Hakim (1986) penambahan pupuk kandang sebagai salah satu bahan organik dapat mempertinggi humus dan mendorong kehidupan jasad renik tanah yang akan membantu proses dekomposisi bahan organik. Hasil penelitian yang diperoleh ini lebih tinggi dari hasil penelitian Tacoh et al. (2017) yang menghasilkan berat malai $377 \mathrm{~g}$ dengan menggunakan bokashi feses

Tabel 1. Rataan Pengaruh Perlakuan Pupuk Bokashi Feses Sapi terhadap Tinggi Tanaman dan Berat Malai.

\begin{tabular}{|c|c|c|c|c|c|}
\hline \multirow{2}{*}{ Variabel } & \multicolumn{4}{|c|}{ Perlakuan } & \multirow{2}{*}{ Significan } \\
\hline & PO & $\mathrm{P} 1$ & P2 & P3 & \\
\hline Tinggi tanaman & $139,2 \pm 7,98^{a}$ & $151,8 \pm 5,07^{b}$ & $164,2 \pm 5,17^{c}$ & $168,2 \pm 5,22^{c}$ & Sig \\
\hline Berat malai & $282,6 \pm 20,78^{a}$ & $282,6 \pm 36,47^{a}$ & $358,0 \pm 23,02^{b}$ & $377,8 \pm 22,02^{b}$ & Sig \\
\hline
\end{tabular}

Tabel 2. Rataan Pengaruh Perlakuan Pupuk Bokashi Feses Sapi terhadap Jumlah Anakan, Tinggi Tanaman dan Berat Malai.

\begin{tabular}{|c|c|c|c|c|c|}
\hline \multirow{2}{*}{ Variabel } & \multicolumn{4}{|c|}{ Perlakuan } & \multirow{2}{*}{ Significan } \\
\hline & PO & P1 & $\mathrm{P} 2$ & P3 & \\
\hline Jumlah anakan & $3,47 \pm 0,22^{a}$ & $4,89 \pm 0,18^{b}$ & $5,98+0,07^{c}$ & $7,02 \pm 0,14^{d}$ & Sig \\
\hline Tinggi tanaman & $147,0 \pm 2,16^{a}$ & $162,6 \pm 7,87^{b}$ & $176,0 \pm 3,47^{b}$ & $196,2 \pm 2,57^{c}$ & Sig \\
\hline Berat malai & $286,0 \pm 18,01^{d}$ & $309,4 \pm 19,76^{a b}$ & $345,6 \pm 13,96^{b c}$ & $387,8 \pm 7,57^{c}$ & Sig \\
\hline
\end{tabular}


sapi. Hal ini diduga makin tinggi dosis bokashi makin banyak unsur hara yang diserap sehingga memberikan sumbangan hara yang besar dalam bobot biji.

\section{Jumlah Anakan}

Pengaruh perlakuan terhadap jumlah tunas dapat dilihat pada Tabel 2. Rataan jumlah anakan tertinggi terdapat pada perlakuan $\mathrm{P}_{3}(7,02)$ diikuti oleh $\mathrm{P}_{2}$ $(5,98), \mathrm{P}_{1}(4,89)$ dan yang terendah pada perlakuan Po $(3,47)$. Hasil analisis sidik ragam menunjukkan bahwa perlakuan pemupukan memberikan pengaruh yang sangat nyata $(\mathrm{P}<0,01)$ terhadap jumlah anakan. Uji lanjut BNJ memperlihatkan bahwa perlakuan P3 menunjukkan perbedaan yang lebih tinggi dibandingkan dengan Po (tanpa pemupukan), P1, dan P2 memberikan pengaruh yang sangat nyata $(\mathrm{P}<0,01)$ terhadap jumlah anakan. Semakin tinggi level pupuk semakin meningkat jumlah anakan tanaman sorgum. Hal ini di karenakan bokashi yang ditambahkan ke dalam tanah dapat mensuplai hara melalui dekomposisi bahan organik, sehingga meningkatkan ketersediaan unsur-unsur hara tersebut dalam tanah (Syam, 2003; Nguyen dan Shindo, 2011). Diketahui bahwa bokashi feses sapi mengandung unsur hara makro dan mikro yang sangat dibutuhkan oleh tanaman sorgum. Unsur hara $\mathrm{N}$ berfungsi sebagai perangsang pertumbuhan tanaman secara keseluruhan, khususnya batang, cabang dan daun (Hakim et al., 1986). Selanjutnya dikatakan bahwa unsur $P$ berfungsi sebagai memacu pertumbuhan akar dan pembentukan sistem perakaran yang baik sehingga tanaman dapat menyerap unsur hara lebih banyak dan pertumbuhan tanaman menjadi sehat dan kuat. Sedangkan unsur $\mathrm{K}$ berfungsi untuk mengaktifkan enzim-enzim yang mempercepat pertumbuhan jaringan meristimatik (Setyamidjaya, 1996). Lanjut dikatakan juga bahwa unsur $\mathrm{K}$ dapat diserap tanaman mengakibatkan pertumbuhan jaringan meristimatik juga akan lebih baik dan pertumbuhan tunas yang menentukan saat tumbuh stek juga akan lebih cepat. Penelitian Riyani et al., (2013) pada tanaman padi yang menggunakan pupuk kotoran sapi lebih tinggi yaitu 8,55 tunas.

\section{KESIMPULAN}

Berdasarkan hasil penelitian yang telah dilaksanakan dapat disimpulkan bahwa pemberian pupuk bokashi feses sapi $12 \mathrm{~kg} /$ petak memberikan pengaruh terbaik terhadap jumlah tunas, tinggi tanaman, dan berat malai tanaman ratun sorgum. Panen ratun menghasilkan tinggi tanaman 16,65\% dan berat malai 2,65\% lebih tinggi dari pada panen pertama.

\section{DAFTAR PUSTAKA}

Atikah T. A. 2013. Pertumbuhan dan hasil tanaman terung ungu varietas yumi F1 dengan pemberian berbagai bahan organik dan lama inkubasi pada tanah berpasir. Anterior Jurnal 12(2):6-12

Gao M., J. Li, and X. Zhang. 2012. Responses of soil fauna structure and leaf litter decomposition to effective microorganism treatments in Dahinggan Mountains, China. Chinese Geographical Science. Journal Vol 22(6): 647-658.

Hakim N., M. Y. Nyakpa, A. M. Lubis, S. G. Nugroho, M. A. Diha, Go Ban Hong, dan H. Bailey. 1986. Dasar-Dasar Ilmu Tanah. Penerbit Universitas Lampung.

Imban S. S., A. Rumambi, S. S. Malalantang. 2017. Pengaruh pemanfaatan bokashi feses sapi terhadap pertumbuhan sorgum varietas kawali. Jurnal Zootek. Vol. 37(1): 80- 87

Mekbib F. 2009. Farmers breeding of sorghum in the centre of diversity, Ethiopia: socio-ecotype differentiation, varietal mixture and selection efficiency. Journal Maydica. 54:25-37.

Nguyen T.H., dan H. Shindo. 2011. Effects of different levels of compost application on amounts and distribution of organic nitrogen forms in soil particle size fractions subjected mainly to double cropping. Journal Agricultural Sciences 2(3): 213-219.

Puspitasari G., D. Kastono, S. Waluyo. 2012. Pertumbuhan dan hasil sorgum manis (Sorghum bicolor (L.) Moench) tanam baru dan ratoon pada jarak tanam berbeda. Jurnal Vegetalika. 1(4):18-29.

Riyani R., Radian, dan S. Budi. 2013. Pengaruh berbagai pupuk organik terhadap pertumbuhan dan hasil padi di lahan pasang surut. Fakultas Pertanian. Universitas Tanjung Pura. Jurnal sains mahasiswa pertanian Vol 2 (2):1-11

Ruhukai N. L. 2011. Pengaruh penggunaan EM4 yang dikulturkan pada bokashi dan pupuk anorganik terhadap produksi tanaman kacang tanah (Arachis hypogaea L.) di Kampung Wanggar Kabupaten Nabire. Jurnal Agroforestri VI(2):114120.

Rumambi A. 2012. Penyediaan pakan berkelanjutan melalui inokulasi fungi mikoriza arbuscula dan aplikasi fosfat alam pada Arachis pintoi dalam tumpang sari dengan jagung atau sorgum. Disertasi. Sekolah Pascasarjana Institut Pertanian Bogor.

Rumambi A. 2013. Karakteristik pertumbuhan sorgum dengan pemupukan urea berbeda sebagai sumber nitrogen. Jurnal Agrosistem Vol 10 (1): 1-12.

Sarief E. S. 1986. Kesuburan dan Pemupukan Tanah 
Pertanian. Pustaka Buana. Bandung.

Setyamidjaja D. 1996. Pupuk dan Pemupukan. Sinaplex

Djakarta. 122 hal.

Steel G. D. dan J. H. Torrie. 1991. Prinsip dan Prosedur Statistika Suatu Pendekatan Biometrik. Edisi kedua. Gramedia Pustaka Utama. Jakarta.

Syam A. 2003. Efektivitas pupuk organik dan anorganik terhadap produktivitas padi dilahan sawah. Jurnal Agrivigor 3(3):232-244.

Tacoh E., A. Rumambi, W. B. Kaunang. 2017. Pengaruh pemanfaatan pupuk bokashi feses sapi terhadap produksi sorgum varietas kawali. Jurnal Zootek. Vol. 37 (1): 88 - 95 